\title{
Flight Activity Periods of the Sugarcane Borer, Diatraea saccharalis, in Puerto Rico
}

\author{
Frank W. Fisk and Rafael Pérez Pérez'
}

\section{INTRODUCTION}

The timing of flight and mating activities of Louisiana populations of the sugarcane borer moth, Dialrasa saccharalis (Fabr.), have been reported by Pérez and Long (5) ${ }^{2}$, Pérez (4), and Hammond (1). These observations were simplified by the discovery of a potent pheromone in this species (5) which made possible the use of sticky traps baited with live unmated female moths or extracts from them.

In Louisiana most flight activity begins after midnight, with a peak at 3 a.m. (4). Hammond (1) noted that in a walk-in light trap no mating was observed before 3 a.m. However in Puerto Rico, Walker (6) reported that flight activity and mating occurs "in nature as early as 8 p.m. to as late as 3:30 a.m." The study reported here was carried out in an effort to investigate these apparent behavioral differences between the North American and Puerto Rican populations of Diatraea saccharalis.

\section{METHODS AND MATERIALS}

The black light traps were of a commercially available 15 -W type $\mathrm{BL}$ fluorescent model fitted with a screw cap under the funnel opening. A polyethylene plastic "Mason" jar fitted the screw cap. A 4-mesh hardware cloth screen laid in the funnel kept out the largest insects and could also support a bait container. The unmated female moths (bait) were held in a $11 / 2$ ounce flip-top plastic container ( 6 per container) screened at both ends. Each bait container had short wire supports by which it could be readily detached from or attached to the light traps or bait traps. The bait traps consisted of 1-gallon tin cans open at both ends in which paper liners coated with Strikem ${ }^{\oplus}$ were placed. A can was placed about 5 feet from the ground by means of a wire support hooked over the leaf axil of a mature cane plant. The bait-container was then fastened into place in the center of the can.

Unmated female moths were made available from a mass rearing program currently in progress. The insects were sexed and separated as pupae in

1 Professor of Entomology, Faculty of Jint omology, Ohio State Eniversity, Columbus, Ohio, and Assistant Entomologist, Fortuna Agricultural Experiment Substation, Mayagüez Campus, University of Puerto Rico. The authors wish to thank Mercedita Central for permission to make these field studies on their property. Thanks are also due to José Autonio Santiago for technical assistance.

2 It alic numbers in parentheses refer to Literature Cited, pp. 98-9. 
order to secure unmated females. A partly synthetic (meridic) diet based on that developed at Louisiana State University (1) was used to rear separately populations secured from Puerto Rico and Louisiana. At the time of writing the production of females exceeds 100 per day.

The observation area was in a field of infested mature sugarcane about 2 miles from the Fortuna Substation (near Ponce, P.R.). By means of a 500 -foot extension cord, electricity for operating the light traps was obtained from a nearby house. The traps were placed at intervals along an irrigation trench running through the field in such a way that light from either of the two black light traps did not reach any other trap.

Observations were made on four different nights in February and March, 1968, two of them near full moon and two with almost no moonlight. Minimum temperatures ranged between $62^{\circ}$ and $65^{\circ} \mathrm{F}$. on these nights. During each night hourly removal of male moths from the bait traps and all insects from the light traps were made. Black light trap catches, in soapy water, were transferred to separate 2-ounce plastic vials at each hour. A small volume of formalin was then added to each vial to preserve the contents for examination later.

\section{RESULTS AND DISCUSSION}

The results are summarized in table 1. Catches from the bait traps, which were all male sugarcane borel moths, were totaled separately for the nights during bright moonlight and those with no moon. There is an indication that flight begins early at night, with a peak before 9 p.m., but this is based on very high catches in just one trap and may be of little significance. It is obvious however, that some male moths are flying from before 8 p.m. until 4 a.m. in both moonlight and dark nights.

The light trap catches offer several clues to flight behavior of the moths. No female moths were captured on bright moonlight nights (figure 1) as compared with a total of 18 on dark nights (figure 2). This could be interpreted as a near absence of flight activity in bright moonlight, but may also reflect a lowered attractiveness of the ultraviolet light in the presence of moonlight. On the other hand, male catches were higher in bright moonlight nights than with no moon. On the dark nights (when both sexes were collected) the females showed a flight peak before 10 p.m., while one male flight peak was near 11 p.m., and another before 4 a.m.

In comparing baited versus unbaited light traps it was found that, on a per-trap bassis, the baited traps caught more males but slightly fewer females. The differences were considered insignificant. However this may have been caused by the relative locations of the two traps. The baited trap was nearer the edge of the field, which, in a previous test, caught fewer moths. Hoffman, et al. (S) have reported that, in capturing tobacco hornworm 
moths, black light traps baited with unmated female moths are far more effective than unbaited traps.

As can be seen from table 1 no males were found in the bait traps after

TAHLE 1.-Number of sugarcane borer moths caplured by bail and black light traps near Forluna, P.R.

\begin{tabular}{|c|c|c|c|c|c|c|c|}
\hline \multirow{2}{*}{$\begin{array}{l}\text { Hour of } \\
\text { the night }\end{array}$} & \multirow{2}{*}{$\begin{array}{l}\text { Sex of } \\
\text { moths }\end{array}$} & \multicolumn{4}{|c|}{ Pheromone bait traps 1} & \multicolumn{2}{|c|}{ Black light traps } \\
\hline & & $\begin{array}{c}\text { Bright } \\
\text { moon } \\
(5 \text { t.n. })^{2}\end{array}$ & $\begin{array}{c}\text { No } \\
\text { moon } \\
(5 \text { t.n. })\end{array}$ & $\begin{array}{l}\text { Bright } \\
\text { moon } \\
(t \text { t.n. })\end{array}$ & $\underset{\substack{\text { Moon } \\
(t \text { t.n. })}}{\text { coon }}$ & $\begin{array}{l}\text { Baited' } \\
\text { (5 t.n.) }\end{array}$ & $\begin{array}{c}\text { Unbaited } \\
(3 \text { t.n. })\end{array}$ \\
\hline \multirow[t]{2}{*}{8 p.m. } & $\mathbf{M}$ & 6 & 1 & 0 & 0 & 0 & 0 \\
\hline & $\mathbf{F}$ & & & 0 & 1 & 1 & 0 \\
\hline \multirow[t]{2}{*}{9} & $\mathbf{M}$ & 1 & 22 & 2 & $\mathbf{0}$ & 2 & 0 \\
\hline & F & & & 0 & 1 & 0 & 1 \\
\hline \multirow[t]{2}{*}{10} & $\mathbf{M}$ & 2 & 12 & 3 & 3 & 4 & 2 \\
\hline & $\mathbf{F}$ & & & $\mathbf{0}$ & 7 & 3 & 4 \\
\hline \multirow[t]{2}{*}{11} & $\mathbf{M}$ & 15 & 8 & 7 & 5 & 9 & 3 \\
\hline & $\mathbf{F}$ & & & 0 & 2 & 1 & 1 \\
\hline \multirow[t]{2}{*}{12} & M & 15 & 5 & 6 & 3 & 5 & 4 \\
\hline & $\mathbf{F}$ & & & 0 & 2 & 2 & $\mathbf{0}$ \\
\hline \multirow[t]{2}{*}{1 a.m. } & $\mathbf{M}$ & 9 & 4 & 5 & 3 & 5 & 3 \\
\hline & $\mathbf{F}$ & & & 0 & 1 & 1 & 0 \\
\hline \multirow[t]{2}{*}{2} & $M$ & 14 & 7 & 5 & 2 & 5 & 2 \\
\hline & $F$ & & & 0 & 2 & 1 & 1 \\
\hline \multirow[t]{2}{*}{3} & $\mathrm{M}$ & 4 & 6 & 4 & 1 & 5 & 0 \\
\hline & $\mathbf{F}$ & & & 0 & 1 & 1 & 0 \\
\hline \multirow[t]{2}{*}{4} & M & 1 & 0 & 0 & 5 & 2 & 3 \\
\hline & $\mathbf{F}$ & & & 0 & $\mathbf{0}$ & 0 & 0 \\
\hline \multirow[t]{2}{*}{5} & M & 0 & 0 & 0 & 1 & 1 & 0 \\
\hline & $\mathbf{F}$ & & & 0 & 0 & 0 & 0 \\
\hline \multirow[t]{2}{*}{$6: 30$} & $\mathrm{M}$ & 0 & 0 & 2 & 1 & 3 & 0 \\
\hline & $\mathbf{F}$ & & & 0 & 1 & 0 & 1 \\
\hline \multirow[t]{2}{*}{ otals } & M & bì & 65 & 34 & 24 & 41 & 17 \\
\hline & $F$ & - & - & 0 & 18 & 10 & 8 \\
\hline
\end{tabular}

${ }^{1}$ Baited with 6 ummated female moths per trap (except 4/trap on last test).

2 t.n. = trap night. ( 1 trap for 1 night $=1 \mathrm{t} . \mathrm{n}$.; 3 traps for 1 night or 1 trap for 3 nights $=3$ t.n.).

4 i.m., while the light trap caught moths of both sexes after this time. It is believed that these late captures do not represent extended flight activity, but simply delayed capture. Actual observations during the night often disclosed Diatraea saccharalis moths resting on portions of the light trap or on nearby cane foliage. These could not be recorded until or unless they actually entered the fumnel mouth. The use of a fan in connection with the 
trap as described by Harrell, et al. (2), would correct this inefficiency and trapping delay as well as provide live capture of the sugarcane borer moths for chemosterilization purposes.

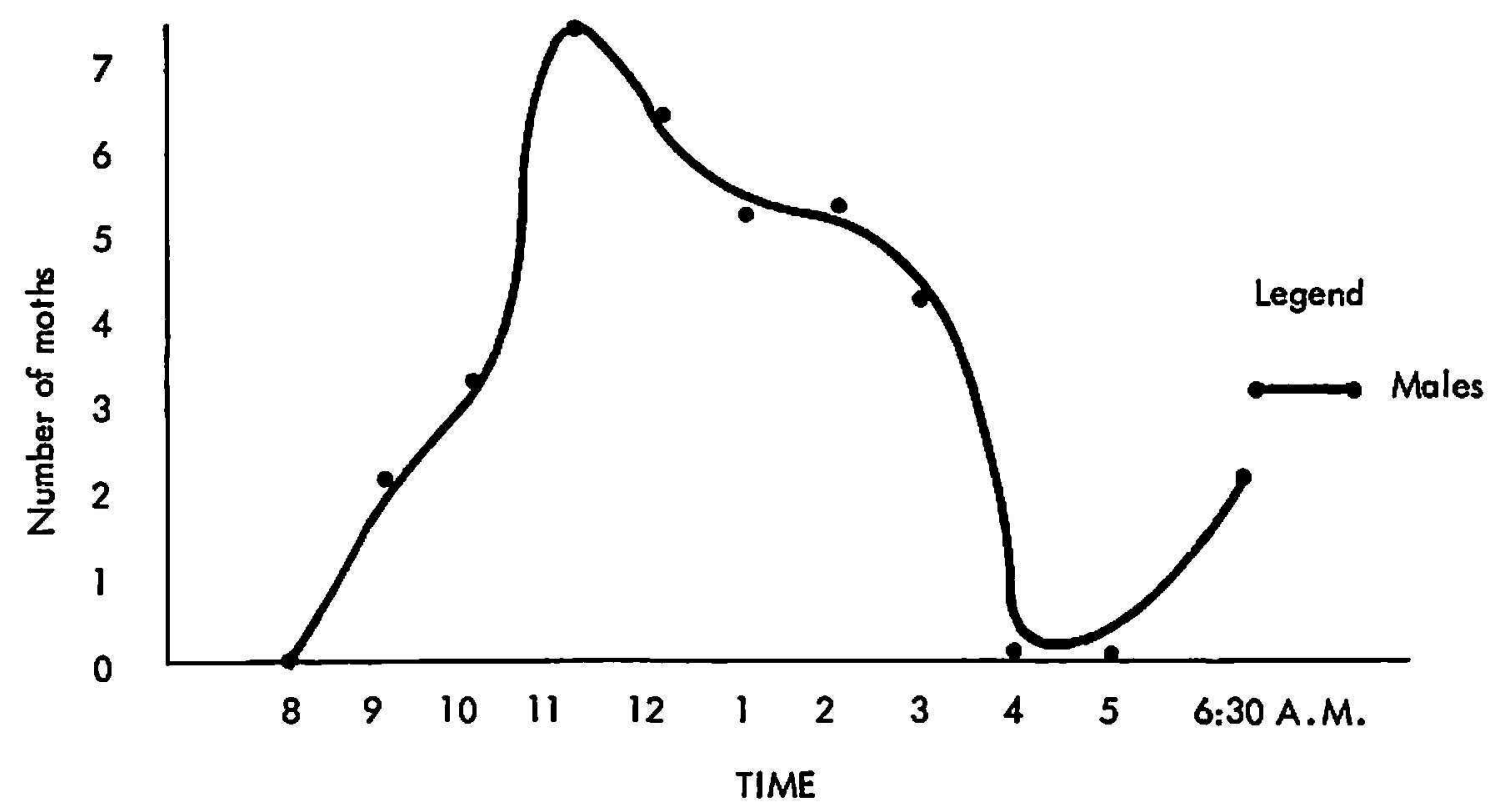

Fig. 1.-Hourly eatches of Dialraea saccharalis in black light traps operating on bright moonlight nights.

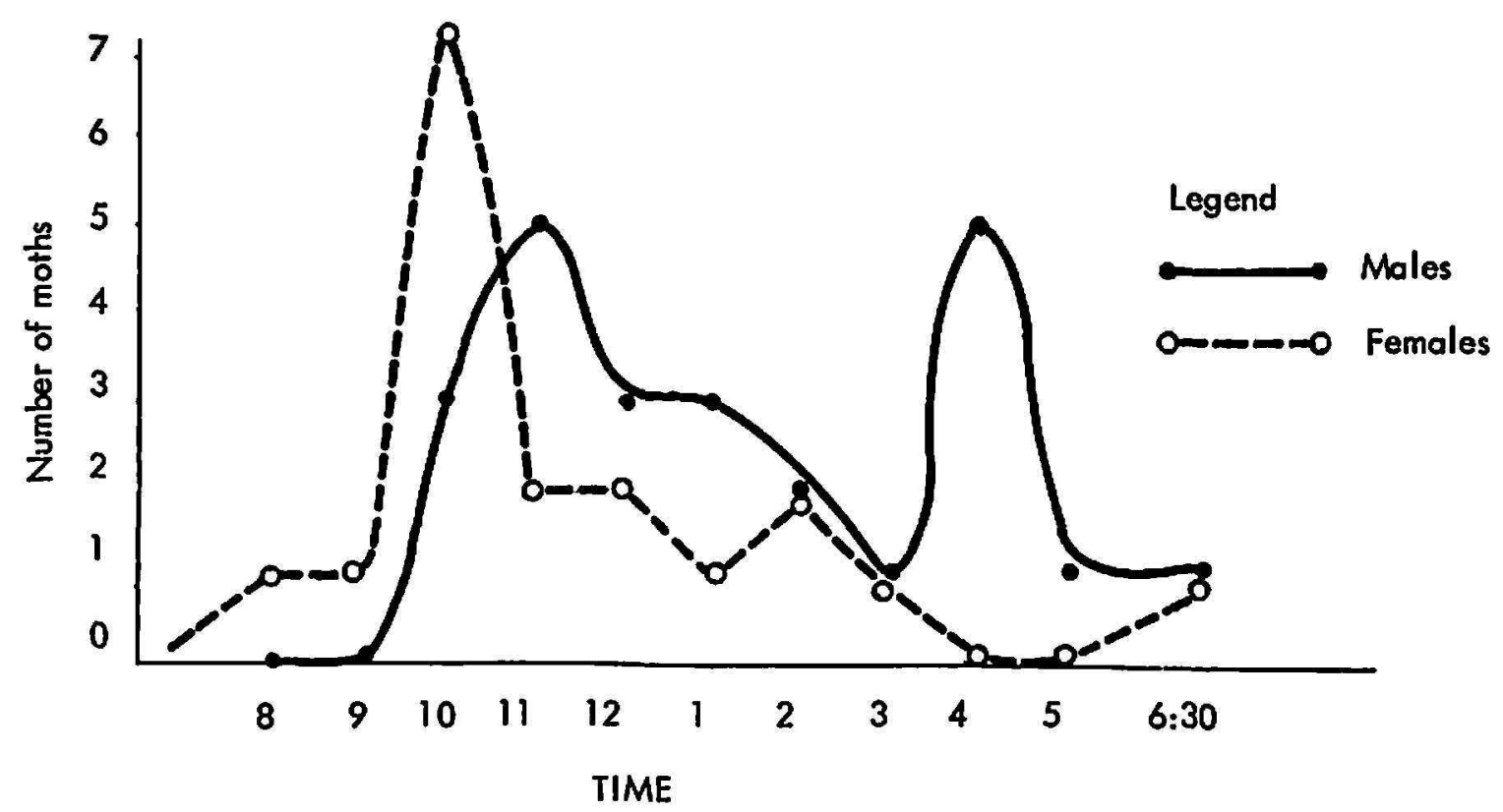

Fra. 2.-IIourly (natches of Diatraca sacharalis in black light traps operating on dark nights.

In the course of this study particular attention was paid to increasing the value of the trapping devices as a means of sampling natural field populations of the sugareane borer. Preliminary studies (4) reported the use of just one unmated female per trap, but, as reported by Hammond (1), additional females per trap increased the catch. However, he kept the 
several females in a single isolated trap, while better results were obtained when the several female moths were together in the same container, provided they had space to vibrate their wings independently and there was sufficient screened opening at either end of the container to disseminate the volatile pheromone effectively.

Pérez (4) showed that unmated females held 2 days after emergence (2-day-old) were slightly more effective than younger or older females in attracting males, but for practical purposes it was simpler to collect females from the emergence cage each morning and hold them just 1 day in the open laboratory.

The use of benzene or methylene chloride extracts from unmated female abdomens, as shown to be effective by Pérez (4) and Hammond (1), would appear to provide a quantitative uniform source of pheromone, thus permitting freedom from a continuous mass rearing program. However the extract traps lose the volatile pheromone rapidly while the live females naturally release the material at the "proper" time, though at other times they are conserving and, presumably, synthesizing more of it. When the exact chemical compound or compounds comprising the pheromone are identified and synthesized (1) it should be possible to develop a reliable synthetic trapping device. The use of bait extract of synthetic pheromone in the black light traps should also improve their efficiency in trapping. The placing of the attractant will require further study. If placed in the funnel mouth or trap jar it may not disseminate properly. If placed in an exposed location it may not attract males to the funnel mouth.

What are the best trap locations for an accurate population survey or population depletion program? Hammond (1) investigated this problem extensively in Louisiana and concluded that the male moths were quite mobile. He found that bait traps about the perimeter of a cane field caught more than when scattered throughout the field. Yet in our experience the bait and light traps toward the center of the field were more effective than those near the edge. Our trap catches indicated a spotty and localized distribution of population within the cane field. While it is true that in other trapping studies with black light traps we have trapped sugarcane borer moths, especially females, at considerable distances (several hundred feet) from the cane fields, the catches are insignificant when compared with captures within an infested field.

\section{SUMMARY AND CONCLUSIONS}

1. Four all-night observations of sugarcane borer moth flight activity using can traps baited with female moths and black light traps were made in an infested sugarcane field.

2. Male moths were trapped from 8 p.m. until 4 a.m. with indications of 
both an early and later flight peak. Thus the Puerto Rican population differs in flight behavior from the same species in Louisiana.

3. Black light traps collected female sugarcane borer moths only on dark nights with little or no moonlight, while male moths were taken by the same traps in greater numbers on bright nights. The baited can traps were equally effective on dark or bright nights.

4. In the light traps the timing of female moth captures was different from the male captures, and showed a single flight peak early in the night.

5. Present experience on the method of construction and baiting of can traps and light traps, and the location of these traps in the field indicates that further improvements are needed before a highly efficient and reliable survey method for Puerto Rican populations of the sugarcane borer moths is achieved.

\section{RESUMEN Y CONCLUSIONES}

1. Durante cuatro noches consecutivas completas se observaron las actividades de vuelo de la mariposa nocturna, adulto del barrenador de la caña de azúcar, para las cuales se usaron trampas que alojaban mariposas hembras como señuelo y trampas con luz negra, en los campos de caña infestados por este insecto.

2. Los adultos machos se atraparon desde las 8 p.m. hasta las 4 a.m., registrándose dos apogeos de vuelo, uno temprano y otro tardío. Asi, la población de estos adultos en Puerto Rico difiere en sus hábitos de vuelo de los de la misma especie en Louisiana.

3. Las trampas de luz negra atraparon adultos hembras del barrenador de la caña de azúcar sólo durante las noches obscuras con poca o ninguna luz lunar, mientras que los adultos machos pudieron atraparse en mayor número y en las mismas trampas en las noches luminosas. Las trampas con adultos hembras como señuelo fueron igualmente efectivas tanto en las noches obscuras como en las claras.

4. La hora en que se capturaron los adultos en las trampas de luz varió de la hora en que se capturaron los adultos machos, registrándose sólo un apogeo de vuelo temprano en la noche.

5. La experiencia actual en cuanto al método de construir y preparar señuelos en las trampas de lata y en las de luz y de localizarlas en el campo indica que es necesario mejorar este método antes de que pueda hacerse un estudio más eficiente y confiable de la población de adultos del barrenador de la caña de azúcar en Puerto Rico.

\section{LITERATURE CITED}

1. Hammond, A. M., Bioassay and field evaluation of the sex attractant in Diatraea saccharalis (F.), PhD. Dissertation, Louisiana State University, 88 pp., 1967. 
2. Harrell, E. A., Hare, W. W., and Young, J. R., A fan for handling live insecte, J. Econ. Entomol. 69: 756-8, 1966.

3. Hoffman, J. D., Lawson, F. R., and Peace, B., Attraction of black light traps baited with virgin female tobacco hornworn moths, J. Econ. Entomol. 69: 809-11, 1866.

4. Pérez Pérez, R., Sex-attractant and mating behavior of the sugarcane moth borer, Bull. 188, Agr. Expt. Sta., Univ. P.R., 28 pp., 1964.

5. Pérez Pérez, R., and Long, W. H., Sex-attractant and mating behavior in the sugarcane borer, J. Econ. Entomol. 55: 419-21, 1964.

6. Walker, D., Induced sterility for population control of the sugarcane borer (Diatraea saccharalis) in Puerto Rico, Tech. Rept. 1, Puerto Rico Nuclear Center, Mayagüez, P. R., 30 pp., 1965. 